\title{
Research on the Development Strategies of Higher Vocational Education in the Framework of Sydney Accord
}

\author{
Liu Wenhua \\ Institute of Higher Technical Education, Shanghai Dianji University, \\ 1350 Ganlan Rd., Pudong New District, Shanghai, China \\ Iwhuajky@163.com
}

Keywords: Washington Accord; Sydney Accord higher vocational education; internationalization

\begin{abstract}
China's engineering education have joined the Washington Accord. This is very meaningful to the internationalization of China's higher education. There are three accord which approve engineering and technical education: Washington Accord, Sydney Accord and Dublin Accord. According to the different object, China's higher vocational education is suitable to Sydney Accord which will be very helpful to its internationalization. China's higher vocational education can learn a lot from Taiwan and Hang Kong. So in the face of the impact from Sydney Accord, China' higher vocational education need some make up a missed lesson so as to meet the new needs.
\end{abstract}

\section{Introduction}

There are three international agreements governing mutual recognition of engineering qualifications and professional competence. They are the Washington Accord, the Sydney Accord and the Dublin Accord. The differences among these three accord are pretty obvious. The Washington Accord recognises substantial equivalence in the accreditation of qualifications in professional engineering, normally of four years duration. The Sydney Accord recognises substantial equivalence in the accreditation of qualifications in engineering technology, normally of three years duration. And the Dublin Accord recognises substantial equivalence in the accreditation of tertiary qualifications in technician engineering, normally of two years duration.

From the differences among these three accord we can see that the type of education which the Washington Accord recognises lines up with undergraduate engineering education in China. While the type of education which the Sydney Accord recognises lines up with higher vocational education in China. Now China has joined the Washington Accord in 2013. Then what does the Sydney Accord mean to China's higher vocational education? How does China's higher vocational education react to the effect of joining the Sydney Accord in the near future?

\section{The necessity of Internationalization of higher vocational education}

We often talk about the internationalization of higher education. But it basically refer to undergraduate education. In my point view, China's higher vocational education also need take action of internationalization. China's joining the Sydney Accord is an opportunity for the internationalization of China's higher vocational education. Here is the reason.

Firstly, the Sydney Accord can help the international competitiveness of China's higher vocational education. Most contracting states of the Sydney Accord have their professional organizations which take charge of not only engineering and technology education accreditation but also engineers and technician qualifications accreditation. So this forma closed loop of quality assurance from education to qualification. In this sense, joining the Sydney Accord can propel the internationalization of China's higher vocational education.

Secondly, the Sydney Accord can help improve the international reputation of China's higher vocational education. Once China joins the Sydney Accord, which means the quality of China's 
higher vocational education has internationally gotten the admission in some extent. At the meantime, it can help the graduates of higher vocational colleges find jobs on an international scale.

\section{The challenges which China's vocational colleges will face when joining the Sydney Accord}

Joining the Sydney Accord can improve the internationalization level and reputation of China's higher vocational education. But the meanwhile, it can lead to some impacts. The challenges which China's vocational colleges will face when joining the Sydney Accord are as following.

In the first place, the impact is the educational idea and concept. From the past two years' experience which China acts as a reserved contract country, the first challenge we are facing is the idea conflict from the Washington Accord. For example, the Sydney emphasizes the continuous improvement, student outcomes and institutional support. These things are despised in China. To make sure of act under the frame of Sydney Accord, we should firstly change our some thoughts and concepts, for instance, education administration, school-running ideas, talents cultivating methods.

In the second place, the impact is the programs setup of China's higher vocational colleges. These international accord like Washington Accord and Sydney Accord encourage the graduates searching for jobs in global labor market. So more and more graduates from China will join the international labor market. On the one hand, it is an advantage for higher vocational colleges, because it means the graduates get more international job-hunting opportunities. On the other hand, it is a challenge, because only those graduates who are high-skilled can get the jobs. So to meet this need, China' higher vocational colleges should adjust the programs setup.

Finally, the impact is curriculum system of China's higher vocational colleges. The Sydney Accord has stipulate the quantity, time, context of some courses, for example, mathematics, science and other courses of liberal arts. Although the Sydney Accord does not stipulate professional courses of different programs, it stipulates the knowledge, capabilities which the graduates of different programs should attain when they get graduated after about three-year study. So this need those relevant courses to meet these needs so as to cultivating the students with enough knowledge and skills. But comparing to the course system of China's higher vocational colleges, they still maintain the trace of discipline curriculum. This phenomena obviously conflict with the original intention of the Sydney Accord.

\section{The coping strategies of China's higher vocational education}

Actually, China's higher vocational colleges face not a few challenges and impacts, but we should not sit there to wait. We should try to find the problems existing in China's higher vocational colleges which conflict to the original intention of the Sydney Accord. Then we do something of make up these shortcomings to lighten its impacts.

Firstly, the pedagogical idea and teaching abilities of instructors should be improved. After the intramural construction programs for several years, for instance, Model Colleges Program, Excellent Courses Program and other similar construction programs. These construction programs contribute to the teachers' concept improvement. But under the frame of Modern Vocational Education System, the education system which is in accordance with the spirit of the Sydney Accord. And this will surely affect the update of teacher's pedagogical idea. So we can use the opportunities of joining the Sydney Accord to propel the update of teacher's pedagogical idea in China's vocational colleges.

In terms of the teaching abilities, we should emphasize the industry experience which teachers ever work in some enterprises. This is because of the character of vocational education. The teachers can teach not only vocational knowledge but also real work skills.

Secondly, China's vocational colleges should lay more stress on student outcomes. Recently, some program assessments have been carried on in China's higher vocational education. But the main character of these program assessment is that focus on the input, for example, area of structure, the quantity of books, experimental facilities and other hardware situation. Indeed these input 
condition is very important to the quality of talent cultivating. But these hardware are just the tools. We should pay attention to the education process and the results. This is an outcome-based thinking. The Sydney Accord attach importance to student outcomes which can be separated to two aspects: professional outcomes and technical outcomes. The professional outcomes are an ability to communicate effectively and the broad education necessary to understand the impact of engineering solutions in a global, economic, environmental, and societal context. The technical outcomes are an ability to apply knowledge of mathematics, science, and engineering, and an ability to design and conduct experiments, as well as to analyze and interpret data. So china's vocational colleges should pay more attention to student outcomes.

Thirdly, the internationalization of China's vocational colleges should be strengthened. As a whole, the internationalization level of China's higher education has gotten lots of improvement. But when we take a closer look, the internationalization of China's higher education mainly lies on undergraduate universities. The internationalization of vocational colleges is still in unsatisfactory situation. In fact the Sydney Accord itself is a reflection and pursuit of education internationalization. So on the basis of the spirit of the Sydney Accord, China's vocational colleges should strengthen their internationalization in pedagogy concept, program development, curriculum system, faculty. At the meantime, higher vocational colleges should reform foreign language teaching to improve the students' application abilities of foreign language. And the administration of higher vocational colleges should reform to meet international standards.

\section{References}

[1] Wang Boqing: Research on Programs Construction of Higher Vocational Education according to the Sydney Accord. Jiangsu Education Vol.7(2014),p.16.

[2] Mai Linyan: Journal of Xiamen City Vocational College Vol.2(2014),p.23.

[3] Lin Wen: Journal of Minjiang College Vol.3(2014),p31.

[4] Fu Wanying: Chinese Vocational and Technical Education Vol.24(2013),p9. 